\title{
Oceanography
}

CITATION

Schofield, O., H. Ducklow, K. Bernard, S. Doney, D. Patterson-Fraser, K. Gorman, D. Martinson, M. Meredith, G. Saba, S. Stammerjohn, and others. 2013. Penguin biogeography along the West Antarctic Peninsula: Testing the Canyon Hypothesis with Palmer LTER observations.

Oceanography 26(3):204-206, http://dx.doi.org/10.5670/oceanog.2013.63.

DOI

http://dx.doi.org/10.5670/oceanog.2013.63

COPYRIGHT

This article has been published in Oceanography, Volume 26, Number 3, a quarterly journal of The Oceanography Society. Copyright 2013 by The Oceanography Society. All rights reserved.

USAGE

Permission is granted to copy this article for use in teaching and research. Republication, systematic reproduction, or collective redistribution of any portion of this article by photocopy machine, reposting, or other means is permitted only with the approval of The Oceanography Society. Send all correspondence to: info@tos.org or The Oceanography Society, PO Box 1931, Rockville, MD 20849-1931, USA. 


\section{Penguin Biogeography Along the West Antarctic Peninsula Testing the Canyon Hypothesis with Palmer LTER Observations}

BY OSCAR SCHOFIELD, HUGH DUCKLOW, KIM BERNARD, SCOTT DONEY, DONNA PATTERSON-FRASER, KRISTEN GORMAN, DOUG MARTINSON, MICHAEL MEREDITH, GRACE SABA, SHARON STAMMERJOHN, DEBORAH STEINBERG, AND WILLIAM FRASER

The West Antarctic Peninsula (WAP) is home to large breeding colonies of the ice-dependent Antarctic Adélie penguin (Pygoscelis adeliae). Although the entire inner continental shelf is highly productive, with abundant phytoplankton and krill populations, penguin colonies are distributed heterogeneously along the WAP (Ducklow et al., 2013, in this issue). This ecological conundrum targets a long-standing question of interest: what environmental factors structure the locations of Adélie penguin "hot spots" throughout the WAP?

Penguin colonies appear to be located in association with deep submarine canyons that are found all along the WAP continental shelf (Figure 1). These deep troughs extend from the shelf break to the land margin. Marine canyons are hypothesized to provide a cross-shelf conduit for warm $\left(>1^{\circ} \mathrm{C}\right)$, modified, Upper Circumpolar Deep Water to the coast. This water mass is the primary heat source within the WAP, and the observed warming of Upper Circumpolar Deep Water (Martinson et al., 2008) is driving regional atmospheric warming (Ducklow et al., 2012) and the observed declines in sea ice in this region (Stammerjohn et al., 2008). In the past, when annual and perennial sea ice dominated these coastal waters, canyons were hypothesized to drive the recurrent formation of polynyas (areas of open water surrounded by sea ice) that provided penguins year-round access to open-water foraging areas. Proximity of reliable foraging areas to breeding colonies is important given the energy costs for breeding parents needing to travel to forage and return to provision and protect chicks.

Close association of major WAP penguin colonies with marine canyons led to a long-standing hypothesis that unique physical and biological processes induced by these canyons produce regions of enhanced prey availability that are predictable over ecological time scales (decades to centuries). Linking the regional physical and ecological dynamics to test the "canyon" hypothesis has in the past been restricted by harsh environmental conditions that limit Zodiac and ship sampling. However, the Palmer Long Term Ecological Research (LTER) network recently expanded its observational efforts by incorporating autonomous underwater sampling and satellite tagging of penguins to increase sampling capabilities at two large Adélie penguin colonies along the WAP.

Anvers Island is a focal site of Palmer LTER efforts (Figure 1). Here, Palmer Deep is a cross-shelf canyon bathymetrically similar to others in the WAP that are also associated with large penguin populations. Satellite-tagged Adélie penguins breeding at Anvers Island appear to forage exclusively within Palmer Deep. A majority of Adélie foraging activity is centered over the canyon edge where the bathymetry rapidly shoals, and around which the spatial variability in foraging is strongly influenced by tides (Oliver et al., 2013). These foraging patterns were used to guide sampling of physical and biological properties using autonomous Webb Slocum gliders. Gliders revealed the uplift of 


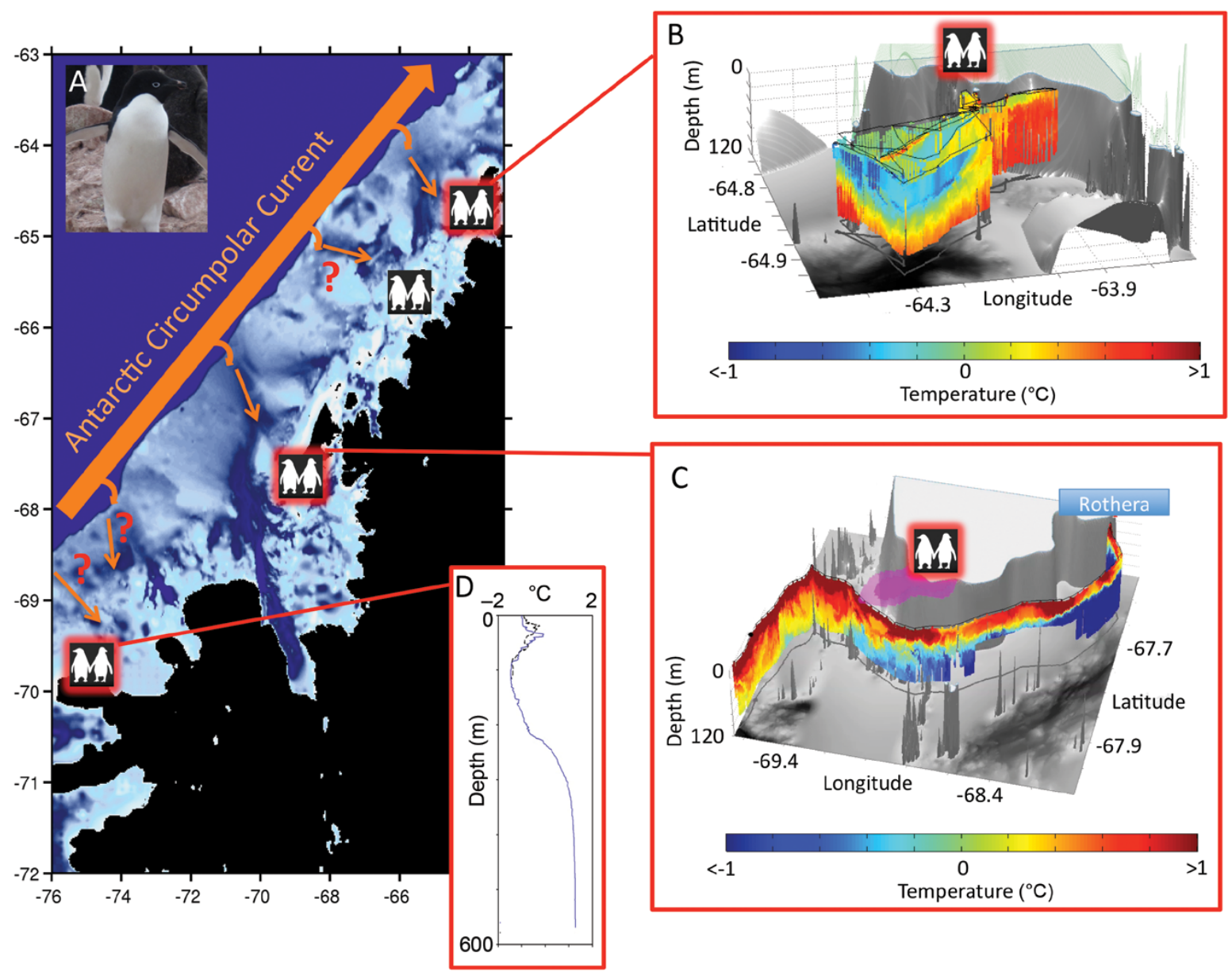

Figure 1. The 1,000 km sampling domain of the Palmer Long Term Ecological Research (LTER) program. (A) Bathymetry of the spatial sampling domain of the Palmer LTER. Orange arrows indicate the Antarctic Circumpolar Current and potential transport to coastal regions. Arrows with question marks indicate hypothesized routes requiring more data. Penguin breeding colonies are indicated by the paired-penguin symbols. For three of the penguin colonies (outlined in red), subsurface data have been collected with an effort to identify the presence of warmer deep waters of the modified Circumpolar Current near the penguin colonies. (B) Slocum glider temperature data collected offshore Palmer Station and its resident penguin colonies, showing the uplift of warm water along the canyon. (C) Glider temperature and penguin foraging data, collected by radio-tags at Avian Island near Rothera Station. The foraging locations are indicated by the surface purple shadow. It is associated with areas where warm water occurs at both surface and at depth. (D) Two temperature profiles measured by ship over the seafloor canyon adjacent to the penguin colony at Charcot Island, showing warm water at depth consistent with the presence of modified Upper Circumpolar Deep Water.

warm deep water along the slope of the canyon (Figure 1B), a hydrographic feature associated with enhanced concentrations of phytoplankton. Furthermore, glider-based measurements of phytoplankton health using a bio-optical measure, $\mathrm{Fv} / \mathrm{Fm}$, the quantum yield for photosystem II activity (Falkowski and Raven, 2007), indicated algal cells at the canyon edge were the healthiest in the region. Net tows and acoustic survey data indicate the presence of abundant krill near the canyon slope.

A second major Adélie breeding colony is located on Avian Island in Marguerite Bay (Figure 1), where chlorophyll and krill concentrations are high. Based on available satellite tag data, penguin foraging is concentrated on the southern flank of Avian Island (Figure 1C). This region is located near the seafloor canyon at the mouth of Marguerite Bay, where gliders revealed shoaling of warm bottom water. In contrast, on the inner reaches of Marguerite Bay by Rothera Base, gliders revealed high chlorophyll but no shoaling of warm bottom water. Penguin foraging does not appear to be significant at the inshore location, further suggesting the importance of warm deep water for foraging at Adélie colonies.

As the WAP warms, it might be expected that conditions surrounding breeding colonies in the south may become more favorable as sea ice and perennial land-fast ice continues to decline. This situation motivated the Palmer LTER program to expand its regional sampling grid to the south. Charcot Island, newly accessible following the collapse of the Wilkins Ice Shelf 
in 2008, borders the southern boundary of the new Palmer LTER regional grid. During our first exploration in 2009, the Palmer LTER team conducted only the third known landing on Charcot Island in the last century. We discovered the continued presence of a rarely documented breeding colony of Adélie penguins (Henderson, 1976). Consistent with our canyon hypothesis, a previously unmapped $800 \mathrm{~m}$ deep seafloor canyon was discovered adjacent to the penguin colony. Conductivity-temperaturedepth (CTD) profiles within the canyon revealed warm $\left(>1.2^{\circ} \mathrm{C}\right)$ water at depth ( $>200 \mathrm{~m})$, consistent with the presence of modified Upper Circumpolar Deep Water (Figure 1D). The canyon was first located by the presence of a polynya, consistent with the hypothesis that canyons result in predictable access to open water for penguin foraging.
Shipboard measurements at the Charcot Island canyon revealed high concentrations of phytoplankton, bacteria, and krill. Satellite tags confirmed penguin foraging near the canyon. Subsequent visits also confirmed the sustained presence of the Charcot penguin colony; however, poor-quality bathymetric data requires future surveying to map the link between the nearshore seafloor canyon and the outer shelf. We discovered that navigational charts have Charcot Island misplaced by $5 \mathrm{~km}$ in this previously inaccessible region.

In conclusion, major WAP Adélie penguin colonies appear to be located in close proximity to the heads of seafloor canyons (although the presence of seafloor canyons does not assume an association with a penguin breeding colony). This connection may in part reflect that marine canyons can provide a conduit

Oscar Schofield (oscar@marine.rutgers.edu) is Professor, Coastal Ocean Observation Laboratory, Institute of Marine and Coastal Sciences, School of Environmental and Biological Sciences, Rutgers University, New Brunswick, NJ, USA. Hugh Ducklow is Professor, Lamont-Doherty Earth Observatory of Columbia University, Palisades, NY, USA. Kim Bernard is Assistant Professor, College of Earth, Ocean, and Atmospheric Sciences, Oregon State University, Corvallis, OR, USA. Scott Doney is Senior Scientist, Marine Chemistry \& Geochemistry Department, Woods Hole Oceanographic Institution, Woods Hole, MA, USA. Donna Patterson-Fraser is a seabird ecologist at the Polar Oceans Research Group, Sheridan, MT, USA. Kristen Gorman is a researcher with the Polar Oceans Research Group, Sheridan, MT, USA, and a PhD candidate in the Department of Biological Sciences, Simon Fraser University, Burnaby, BC, Canada. Doug Martinson is Doherty Senior Research Scientist, Lamont-Doherty Earth Observatory of Columbia University, Palisades, NY, USA. Michael Meredith is Science Leader, British Antarctic Survey, Cambridge, UK, and Honorary Professor, Scottish Association for Marine Science, Oban, UK. Grace Saba is Assistant Research Professor, Coastal Ocean Observation Laboratory, Institute of Marine and Coastal Sciences, School of Environmental and Biological Sciences, Rutgers University, New Brunswick, NJ, USA. Sharon Stammerjohn is Assistant Adjunct Professor of Ocean Science, Institute of Arctic and Alpine Research, University of Colorado, Boulder, CO, USA. Deborah Steinberg is Professor, Virginia Institute of Marine Science, College of William \& Mary, Gloucester Pt., VA, USA. William Fraser is President and Lead Investigator, Polar Oceans Research Group, Sheridan, MT, USA.

for warm Upper Circumpolar Deep Water near the coast. Taken together, these results emphasize the importance of geology in structuring the spatial heterogeneity of ecosystems.

\section{ACKNOWLEDGEMENTS}

Palmer LTER is supported by NSF grant OPP-0823101 and the Gordon and Betty Moore Foundation (1859). Some of the data for this paper was drawn from the Rothera Time-Series (RaTS), a component of the Polar Oceans research program, funded by the British Antarctic Survey. 囵

\section{REFERENCES}

Ducklow, H., A. Clarke, R. Dickhut, S.C. Doney, H. Geisz, K. Huang, D.G. Martinson, M.P. Meredith, H.V. Moeller, M. Montes-Hugo, and others. 2012. Marine pelagic ecosystems: The West Antarctic Peninsula. Pp 121-149 in Antarctica: An Extreme Environment in a Changing World. A.D. Rogers, ed., Wiley.

Ducklow, H.W., W.R. Fraser, M.P. Meredith, S.E. Stammerjohn, S.C. Doney, D.G. Martinson, S.F. Sailley, O.M. Schofield, D.K. Steinberg, H.J. Venables, and C.D. Amsler. 2013. West Antarctic Peninsula: An ice-dependent coastal marine ecosystem in transition. Oceanography 26(3):190-203, http:// dx.doi.org/10.5670/oceanog.2013.62.

Falkowski, P.G., and J.A. Raven, 2007. Aquatic Photosynthesis. Blackwell Scientific Publishers, Oxford.

Henderson, I. 1976. Summer log of travel and work of sledge kilo in northern Alexander Island and Charcot Island, 1975/1976. British Antarctic Survey internal report ref. T/1975/K11.

Martinson, D.G., S.E. Stammerjohn, R.A. Iannuzzi, R.C. Smith, and M. Vernet. 2008. Western Antarctic Peninsula physical oceanography and spatio-temporal variability. Deep Sea Research Part II 55:1,964-1,987, http://dx.doi.org/ 10.1016/j.dsr2.2008.04.038.

Oliver, M.J., A. Irwin, M. Moline, W. Fraser D. Patterson, O. Schofield, and J. Kohut. 2013. Adélie penguin foraging location correlated to local tides. PLoS ONE 8(1):e55163, http:// dx.doi.org/10.1371/journal.pone.0055163.

Stammerjohn, S.E., D.G. Martinson, R.C. Smith, and R.A. Iannuzzi. 2008. Sea ice in the western Antarctic Peninsula region: Spatiotemporal variability from ecological and climate change perspectives. Deep Sea Research Part II 55:2,041-2,058, http://dx.doi.org/ 10.1016/j.dsr2.2008.04.026. 